\title{
Utilizing Salvinia molesta as Alternative Protein Source in Broiler Diet and the Effect on Performance, Breast Muscle and Abdominal Fat
}

\author{
Gena, $F^{1}$., L. D. Mahfudz ${ }^{2}$ and Sumarsono ${ }^{3}$ \\ ${ }^{1,2,3}$ Faculty of Agriculture and Animal Sciences, Diponegoro University, Semarang, 50275, Central Java, \\ Indonesia.
}

\begin{abstract}
The objective of this study was to utilize the invasive aquatic weed, Salvinia molesta as an unconventional and alternative plant protein source in the broiler feeding operation. A total of 100, 15 days of age Lohman strain broilers with initial mean body weight of $\pm 773.83 \mathrm{~g}$ were used in this experiment. The experimental design was Completely Randomized Design (CRD) with 4 dietary treatments consisted of Salvinia molesta meal as follows; T0 (control diet), T1 (diet with 6\% Salvinia molesta), T2 (diet with 12\% Salvinia molesta) and T3 (diet with 18\% Salvinia molesta) and each treatment was replicated five times with five chicks per experimental unit. Feed and water was offered ad libitum from day 15 to 42 and the chicks were vaccinated against Newcastle Disease and Gumboro at 4 and 15 days old. The parameters measured were feed intake, body weight gain and feed conversion ratio, final live weight, breast muscle and abdominal fat. The data was analyzed using analysis of variance (ANOVA) and F-test with the aid of statistical analytical program (SPSS, version 16) and for mean comparison Duncan Multiple Range Test (DMRT) was applied after significant treatment difference $(P<0.05)$. Maximum mean body weight gain per bird/day $(34.39 \mathrm{~g})$ was achieved by chickens on control diet which was statistically significant to birds fed Salvinia molesta diets. However, chickens on diet T1 also attained a significantly higher body weight gain $(28.22 \mathrm{~g})$ to treatments T2 $(22.30 \mathrm{~g})$ and T3 (19.33 g). Better feed conversion ratio was observed with chickens fed the control (4.01) and T1 (4.85) which were similar while deteriorating feed conversion ratio was observed with T2 (6.27) and T3 (7.14) which were similar. The difference between the former and latter treatment groups was significant $(P<0.05)$. Maximum mean final live weight (1758.72 g) was gained with chickens on control diet followed by T1 (1573.56 g), T2 $(1371.03 \mathrm{~g})$ and T3 $(1226.60 \mathrm{~g})$. The differences were significant $(P<0.05)$. Significantly $(P<0.05)$ higher breast muscle percentage (39.20\%) was noticed on control diet followed by T1 (34.52\%), T2 (30.05\%) and T3 (28.61). Abdominal fat was similar for control $(2.26 \%)$ and $T 1$ (2.07) which were significant $(P<0.05)$ to $T 2$ $(1.12 \%)$ and $73(0.70 \%)$. Based on these results the inclusion of $6 \%$ Salvinia molesta in the Lohman broiler diet can be recommended since the effects on the chickens are favorable and similar with respect to the control diet.
\end{abstract}

Key words: Broiler, invasive aquatic weed, Lohman, Salvinia molesta, unconventional protein

\section{Introduction}

Broiler feed cost represents the largest segment $(60-70 \%)$ of the total broiler operation and protein accounts for $15 \%$ of the total cost (Ojewola et al., 2005) and this makes protein an important and economic feed ingredient in the broiler ration. Therefore, in the best interest of the industry both the producers and researchers should identify alternative feed resources especially the ones which are naturally and abundantly available in the environment, relatively cheap to produce, eco-friendly and pose less competition with human nutrition and other industrial applications. Among the many aquatic plants Salvinia molesta can provide a rather cheap and quality alternative protein for the broiler chickens.

This aquatic plant is classed as one of the invasive and noxious aquatic weeds due to its rapid growth rate which can cover water bodies in short period of time and thus cause serious socioeconomic and environmental damages that will directly affect both human and animal life. When under optimal growing conditions, the infestation can double in number and biomass in less than 3 days which can produce within a year as much as 45.6 to 109.5 t/ha in fresh weight (McFarland et al., 2004) while the annual dry weight is assumed to be $110 \mathrm{t}$ dry matter/ha (Mitchell and Tur, 1975 as cited by Moozhiyil and Pallauf, 1986). The rapid growth and mass production of biomass in dry matter basis if utilized as an alternative animal feed component will mean that feed will be available all year round hence this invasive weed could become an asset. This plant can assimilate nitrogen and other minerals from the water bodies and such researchers have trialed this plant in poultry (Zulkarnain and Syahruddin, 2008; Ma'arifah et al., 2013; Zaman et al., 2013) and the results are very promising. Since soybean meal is not available in most countries and coupled with its stiff prices it is important to reduce the use of soybean meal in the broiler diet and replace it with the Salvinia molesta meal. Therefore, in this study Salvinia molesta was used as a source of unconventional protein source to replace the traditionally 
used soybean meal in the diet of broilers and investigated the performance, breast muscle and abdominal fat deposition among the birds.

\subsection{Research Materials}

\section{Research Materials and Methods}

Salvinia molesta (S.molesta) was collected at a nearby pond (Rawa Pening, Semarang) and prior to sun drying the roots like hairs were separated from the main fronds in order to reduce the fiber content of the plant. After sun drying the plants were grounded manually and kept in airtight polythene plastic bags until the day of usage. Samples of S.molesta and the rest of the ingredients used were analyzed for proximate components using methods as stated by AOAC (1990).

The unsexed Lohman broiler chicks were obtained at a commercial hatchery and placed in a temporary brooder for the first 14 days. At day $15^{\text {th }}$ the 100 chicks were selected by body weight and the average body weight was $\pm 773.83 \mathrm{~g}$.

Prior to the arrival of chicks the house was cleaned well and all necessary equipments were made available such as cages, feed (commercial and experimental diets), vaccines (ND and Gumboro), water trough, feeding holder, electric bulb (source of heat) and thermometer in the poultry house. Each cage contained a drinker, feeder and an electric bulb.

\subsection{Research Methods}

\subsubsection{Experimental Design}

The experimental design used in this research is a Completely Randomized Design (CRD) with 4 dietary treatments and five replications of five birds per experimental unit. The treatments applied in this study are as follows;

$\mathrm{T} 0=$ Control diet (without Salvinia molesta)

$\mathrm{T} 1=$ Diet with $6 \%$ Salvinia molesta

$\mathrm{T} 2=$ Diet with $12 \%$ Salvinia molesta

$\mathrm{T} 3=$ Diet with $18 \%$ Salvinia molesta

\subsubsection{Research Procedure}

In the preliminary period (from day 1 to day 11) the DOC were fed a standard commercial starter diet ad libitum purposely to equalize the initial body weights then were fed the adaptation diet (basal diet) for a 3 day period. The basal diets consisted of corn-soybean meal as the main ingredients and formulated to meet the nutritional requirements of broilers (NRC, 1994), but soybean meal was reduced and substituted by S.molesta in the diets as shown in Table 2. The experimental diets were fed as mash and formulated to maintain a similar metabolic energy content of $2900 \mathrm{kcal} / \mathrm{kg}$ in both the starter and finisher diets but protein content was reduce from 20 to $19 \%$ in starter and finisher diets respectively.

At 15 days old, the chicks were weighed individually, foot tagged and allotted to one of the 4 dietary treatments in a completely randomized design (CRD). The broiler birds were vaccinated against Newcastle Disease (ND) twice, on the $4^{\text {th }}$ and along with Gumboro vaccine on $15^{\text {th }}$ days old.

The experimental starter diet was fed when the birds were 15 days old and lasted for 7 days while the experimental finisher diet was fed beginning at day 22 and ran over a period of 21 days. All feed and water was offered ad libitum. The chickens were raised in a temporary made bamboo floor pen $(1 \mathrm{~m} \times 1 \mathrm{~m})$ with a rice straw littered floor $(5 \mathrm{~cm}$ depth). The photoperiod was $16 \mathrm{~h}$ for the first 21 days then reduced to $12 \mathrm{~h}$ during the rest of the finisher phase.

\subsubsection{Research Parameters and Collecting Data}

The daily feed intake (FI) per pen was recorded using a weighing scale and the unconsumed feed was weighed again after consumption for the feed conversion ratio (FCR) determination. Feed intake was expressed as $\mathrm{g} /$ head/day at the end of the feeding trial. Prior to given the experimental feed and allotment into various treatments at day $15^{\text {th }}$ the birds were weighed individually. Body weight gain (BWG) was determined by subtracting the end of the day BW with the previous day BW and expressed as BWG g/head/day for the entire $28 \mathrm{~d}$ experiment period. Feed conversion ratio (FCR) was determined by dividing the daily FI (g) by the daily BWG (g), (FCR = FI / BWG). Mean final live weight (FLW) was determined by weighing the birds with a weighing scale at the end of the trial. At the end of the experiment one bird/experimental unit (i.e., 5 chickens/treatment) was randomly selected for the determination of the breast muscle and abdominal fat components of the carcass. Slaughtering was through severing the jugular vein. After 4 minutes of bleeding each bird was dipped in a water bath for two minutes and feathers were manually plucked by hand. After the removal of the head carcass were manually eviscerated to determine the breast muscle and abdominal fat weights. 
Abdominal fat was removed from parts around the viscera and gizzard and weighed to the nearest gram and expressed as percentage of FLW.

\subsubsection{Statistically Analysis}

The experiment was conducted using completely Randomized Design (CRD) having 4 dietary treatments and 5 replications with 5 chicks per treatment. Data was subjected to ANOVA and Duncan Multiple Range Test (DMRT) was applied after significant $(\mathrm{P}<0.05)$ mean difference among the treatments (Duncan, 1955).

\subsection{Performance}

\section{Result and Discussion}

The effects of the dietary treatments on the performance of the broilers are presented in Table 1. The results indicate that substituting soybean meal with air dried S.molesta had no $(\mathrm{P}>0.05)$ effect on FI whereas FLW, BWG and FCR were affected significantly $(\mathrm{P}<0.05)$. At the end of the experiment period it was observed that with respect to the control diet chickens fed diet T1 had the least average daily FI/day, i.e., $136.86 \mathrm{~g}$ whereas chickens on diet T2 and T3 had slightly higher average daily FI, i.e., $139.73 \mathrm{~g}$ and $137.96 \mathrm{~g}$ respectively. However, the marginal differences of FI according to DMRT were not significant $(\mathrm{P}>0.05)$ between the chickens fed the control and those on various levels of S.molesta.

The similar $(\mathrm{P}>0.05)$ FI observed in the current feeding trial could be related to the closely similar energy content of the diets. Previous studies (Golian and Maurice, 1992; Leeson et al., 1993; Kamran et al., 2008) reported that broilers primarily consume feed to meet their energy requirements and since the current study involved diets formulated to have a closely similar energy content this could have caused the birds to consume relatively similar amount of feed. This result is similar to that reported by Kabir et al. (2005) who observed that feeding various concentrations of Lemna minor $(0 \%, 4 \%, 8 \%, 12 \%)$ to broilers in an isonitrogenous and iso-caloric diet resulted in similar FI among the birds. However, comparing the trend of FI it is obvious that numerically the birds consumed more feed with diets T2 and T3. This could be attributed to the dilution of dietary energy concentration by S.molesta, therefore the birds presumably increased their FI to compensate for the low concentration of available energy and when coupled with the antinutrient factors of S.molesta (Tannin) and high crude fiber content of the diets T2 (10.75\%) and T3 (12.68\%) this condition was imminent. This claim is evident with the low growth rate of the birds provoked by diets T2 and T3. Furthermore, the increase FI with diets $\mathrm{T} 2$ and $\mathrm{T} 3$ can be an attempt by the birds to meet their nutrient requirements (Hill and Dansky, 1954). According to Widyaratne and Drew (2011) FI is influenced by the availability and quality of dietary protein particularly lysine in the amino acid concentration, however, due to the high tannin content from the increase levels of S.molesta as well as crude fiber contents of diets T2 and T3 this could have reduced the amount of dietary lysine hence the birds increased their FI but still their nutrient requirements were not met as evident with the suppressed growth rate with treatments $\mathrm{T} 2$ and $\mathrm{T} 3$. This is in line with Uwalaka et al. (2013) who observed that increased level of tannin content in unripe plantain peel meal (UPPM) caused the birds to increase their FI but still resulted in depressed weight gain of broilers. Contrasting results with the study by Ma'arifah et al. (2013) could attribute to the type of chicken breed/strain and management since their study involved crossbred native chickens (Kampung). The results of the present study also differs with other investigators (Zulkarnain and Syahruddin, 2008; Zaman et al., 2013) and this is primary due to the form in which S.molesta was used. They used fermented S.molesta for their feeding trial whereas air dried S.molesta was utilized in the current study. Further, S.molesta contains tannin which is postulated to have a bitter or astringent taste (Yu, 1995) thus reduces palatability and consequently lower FI and performance, however, palatability was not affected in the current study by using air dried S.molesta and FI was noted to be similar among the treatments, and this can be attributed to solar drying of S.molesta, dietary energy content, and management.

Although FI was similar for all treatments but BWG was affected negatively. The result of BWG per head/day reveals that highest growth rate (34.39) g was achieved by chickens consumed the control diet (T0) followed by T1 $(28.22 \mathrm{~g}), \mathrm{T} 2(22.30 \mathrm{~g})$ and the least growth rate $(19.33 \mathrm{~g})$ was recorded with chickens fed diet T3. According to DMRT the mean value attained with T0 was highly significant $(\mathrm{P}<0.05)$ to all S.molesta containing diets but even T1 mean value also posed significantly to treatments $\mathrm{T} 2$ and $\mathrm{T} 3$. This shows that the birds utilized control diet better than the S.molesta containing diets however, since diet T1 also resulted in significantly higher BWG value to diets $\mathrm{T} 2$ and $\mathrm{T} 3$ it can be assumed that $6 \%$ S.molesta inclusion is the ideal amount since larger amounts caused further drop in BWG. The similar average BWG of the birds observed in chickens fed T2 and T3 diets presumably due to high amounts of S.molesta and crude fiber present in the diets. 
Table 1: Effect of substituting soybean meal with Salvinia molesta on growth performance, abdominal fat and breast muscle of Lohman broilers

\begin{tabular}{lcccc} 
& \multicolumn{4}{c}{ Dietary Treatment $^{1}$} \\
\cline { 2 - 4 } Variables & T0 & T1 & T2 & T3 \\
\cline { 2 - 4 } Mean Initial Body Weight (g) & 795.76 & 783.76 & 754.08 & 761.72 \\
Mean Final Live Weight (g) & $1758.72^{\mathrm{a}}$ & $1573.56^{\mathrm{b}}$ & $1371.03^{\mathrm{c}}$ & $1226.60^{\mathrm{d}}$ \\
Mean Feed Intake (g/head/day) & 137.80 & 136.86 & 139.73 & 137.96 \\
Mean BWG (g/head/day) & $34.39^{\mathrm{a}}$ & $28.22^{\mathrm{b}}$ & $22.30^{\mathrm{c}}$ & $19.33^{\mathrm{c}}$ \\
FCR (g feed / g wt. gain) & $4.01^{\mathrm{a}}$ & $4.85^{\mathrm{a}}$ & $6.27^{\mathrm{b}}$ & $7.14^{\mathrm{b}}$ \\
Abdominal Fat (\% FLW) & $2.26^{\mathrm{a}}$ & $2.07^{\mathrm{a}}$ & $1.12^{\mathrm{b}}$ & $0.70^{\mathrm{c}}$ \\
Breast (\% Carcass wt.) & $39.20^{\mathrm{a}}$ & $34.52^{\mathrm{b}}$ & $30.05^{\mathrm{c}}$ & $28.61^{\mathrm{c}}$ \\
\hline a-c Means with different superscript along the same row differ significantly $(\mathrm{P}<0.05)$ \\
10 = control diet; T1 = 6\% S.molesta in diet; T2 $=12 \%$ S.molesta in diet and T3=18\% \\
S.molesta in diet.
\end{tabular}

Since FI is similar among the treatments the difference in growth rate can be explained in regard to the protein concentration and availability among the dietary treatments. The significant drop in BWG noticed could be due to the reduced protein particularly the amino acid content of diets caused by the presence of tannin and crude fiber content of the diets. Tannins are postulated to have high affinity for proteins with which they interact by hydrogen bonding, hydrophobic association, or covalent bonding (Butler, 1989 as cited by Nyachoti et al. 1996) as well as reduce feed efficiency and nutrient utilization ( $\mathrm{Yu}, 1995)$. Therefore, the presence of tannin could have altered the nutrient utilization and consequently result in the significant reduced BWG in ascending levels of S.molesta among the treatments.

Another possible reason of reduced growth rate could be related to the mineral content of S.molesta. Just like other aquatic plants such as duckweed this plant has the ability to extract minerals from the waterbodies which could affect normal digestion and metabolism. According to a trial done by Phuc et al. (2001) the rats performed better with Lemna minor up to $25 \%$ but $50 \%$ concentration suppressed appetite which resulted in lower growth rate. The authors concluded that unspecified anti-nutritional factors arising from the plant's high mineral content was likely to be inhibiting digestion and metabolism. For this reason it could be assumed that the mineral content of S.molesta could partly be responsible for the reduced growth rate observed among the birds. Based on the result obtained by Ma'arifah et al. (2013), who stated that the crossbred native chickens' performance was enhanced with the addition of S.molesta even up to $18 \%$. This might be related to the chicken types being used in the feeding operation and management aspects.

The result (Table 1) of FCR depicts that the birds fed the control diet (T0) utilized feed better (4.01) and did not differ $(\mathrm{P}>0.05)$ with treatment $\mathrm{T} 1(4.85)$ whereas deteriorating FCR was observed with diets $\mathrm{T} 2$ (6.27) and T3 (7.14) and the difference between the former and the latter treatment groups are significant. Comparing the FCR of diets T0 and T1 with diets T2 and T3 the chickens in the latter two groups (T2 and T3) required a significantly higher amount of feed to attain the BWG of the former two treatment groups (T0 and $\mathrm{T} 1)$, however, FI among treatments are non-significant $(\mathrm{P}>0.05)$.

Better FCR values in birds is the result of FI being parallel with BWG, however, in the present study BWG had a declining trend in increasing levels of S.molesta in the diets and thus poor FCR values are imminent especially with treatments T2 and T3. Dietary energy is one of the major factor to affect FCR of broilers and in the present trial diets were formulated to have a relatively similar values. However, the high feed consumption noticed in treatments T2 and T3 resulted in the depressed BWG in birds and consequently lead to worsen FCR. The presence of antinutrient factors of S.molesta coupled with high crude fiber contents of diets T2 and T3 are the major factors to increase FI of the birds but with suppressed BWG and consequently worsen FCR. It is further proved by Muztar et al. (1978) that aquatic plants do contain high fibre and tannin which would decrease nutrient utilization and ultimately lead to poor FCR. This is also in agreement with by D'Mello (1982) who mentioned that most unconventional feedstuff does contain some antinutritional factors which can affect the performance of the birds.

Although FCR of the control diet was similar with diet T1 and significant to diets T2 and T3 but the general FCR mean values were in an ascending trend, this occurred when the BWG values of chickens were in a descending manner. The relationship between FCR and BWG exhibits the inefficient nutrient utilization by the birds fed S.molesta containing diets which resulted in poor FCR values. In comparison with the result by Zaman et al. (2013) who reported that the best FCR was $0.8825 \pm 0.09$ and this was from using of 50\% S.molesta concentration level. This is so because they used fermented S.molesta prior to being fed to the broiler chickens. They reported that fermentation increased the protein content and decreased the crude fiber amount of S.molesta resulting in improved feed efficiency. But in the present study 6\% air dried S.molesta produced better and consistent results in the broiler chickens then 12 and $18 \%$ levels. This result is generally similar to that observed by Kabir et al. (2005). They observed similar FCR between the control and 4\% Lemna minor concentration in 
the diet but poor values were observed with higher levels ( 8 and 12\%). The general trend was poor values as the level of Lemna minor increased in the diet which is similar to the result of the present study. The main reason of poor FCR's in both studies is related to similar FI but depressed body weight.

Table 2. Nutrient Composition and Calculated Content of the Experimental Diets

\begin{tabular}{|c|c|c|c|c|c|c|c|c|}
\hline \multirow{2}{*}{ Feed Ingredients } & \multicolumn{4}{|c|}{ Starter Diet: 3-4 weeks Period } & \multicolumn{4}{|c|}{ Finisher Diet: 4-7 Weeks Period } \\
\hline & T0 & T1 & $\mathrm{T} 2$ & T3 & T0 & $\mathrm{T} 1$ & $\mathrm{~T} 2$ & T3 \\
\hline Corn & 52.10 & 52.30 & 51.00 & 51.80 & 54.00 & 52.90 & 52.60 & 52.50 \\
\hline Salvinia & 0.0 & 6.00 & 12.00 & 18.00 & 0.00 & 6.00 & 12.00 & 18.00 \\
\hline Soybean meal & 21.30 & 17.00 & 14.00 & 10.80 & 19.30 & 16.50 & 12.70 & 9.40 \\
\hline Vegetable oil & 1.20 & 1.20 & 1.30 & 1.30 & 1.20 & 1.10 & 1.20 & 1.20 \\
\hline Rice bran & 16.80 & 15.90 & 15.10 & 11.80 & 17.70 & 17.60 & 16.40 & 14.60 \\
\hline Fish meal & 5.00 & 5.00 & 5.00 & 5.00 & 4.00 & 3.50 & 3.50 & 3.50 \\
\hline Calcium carbonate & 0.80 & 0.70 & 0.40 & 0.40 & 1.00 & 0.70 & 0.40 & 0.20 \\
\hline Premix & 0.80 & 0.70 & 0.40 & 0.30 & 1.00 & 0.70 & 0.40 & 0.20 \\
\hline Methionine & 1.00 & 0.60 & 0.40 & 0.30 & 0.90 & 0.60 & 0.40 & 0.20 \\
\hline Lysine & 1.00 & 0.60 & 0.40 & 0.30 & 0.90 & 0.60 & 0.40 & 0.20 \\
\hline Total & 100 & 100 & 100 & 100 & 100 & 100 & 100 & 100 \\
\hline $\begin{array}{l}\text { Total Nutrient } \\
\text { Composition } \\
\text { ME (kcal/kg)* }\end{array}$ & 2900.71 & 2900.84 & 2900.31 & 2900.80 & 2902.62 & 2901.51 & 2901.97 & 2902.10 \\
\hline Crude Protein $(\%)^{* *}$ & 20.32 & 20.04 & 20.27 & 20.33 & 19.02 & 19.14 & 19.03 & 19.12 \\
\hline Crude Fat $(\%)^{* *}$ & 5.04 & 4.94 & 4.91 & 4.68 & 5.09 & 4.91 & 4.87 & 4.71 \\
\hline Crude Fiber $(\%)^{* *}$ & 6.22 & 8.36 & 10.57 & 12.10 & 6.31 & 8.68 & 10.75 & 12.68 \\
\hline Methionine $(\%)^{* * *}$ & 1.26 & 0.97 & 0.87 & 0.85 & 1.14 & 0.94 & 0.84 & 0.73 \\
\hline Lysine $(\%)^{* * *}$ & 1.55 & 1.42 & 1.47 & 1.61 & 1.42 & 1.39 & 1.44 & 1.49 \\
\hline Calcium $(\%)^{* * *}$ & 1.24 & 1.77 & 2.10 & 2.73 & 1.36 & 1.65 & 1.98 & 2.41 \\
\hline Phosphor $(\%)^{* * *}$ & 0.72 & 1.05 & 1.39 & 1.70 & 0.68 & 1.02 & 1.35 & 1.68 \\
\hline
\end{tabular}

* ME was calculated with Balton formula as cited by Sibbald (1989)

$\mathrm{ME}=40.81(0.87(\mathrm{CP}+2.25 \mathrm{CF}+\mathrm{BETN})+\mathrm{K}) \mathrm{K}=4.9$

** Proximate Analyzed in Nutrition and Feed Science Laboratory,

Faculty of Animal Science and Agriculture, Diponegoro University

*** Table of Feedstuff Composition by Amrullah (2004)

The results of the final live weight (Table 1) of the broilers had a similar trend to that of BWG. This could be attributed to the influence of antinutrient content of S.molesta and the high dietary crude fiber content of the diets (T2: 10\% CF; T3: 12\% CF). It is therefore, obvious that increasing level of S.molesta in the diet had negative impact on the performance of the birds.

\subsection{Abdominal Fat and Breast Muscle Component}

The abdominal fat and breast muscle components of finisher broilers are important factors used to assess the quality of any given feed. High breast muscle accretion by broilers is regarded as superior while heavy deposit of abdominal fat indicates poor finishing product (Medugu et al., 2010). Therefore, it is the aim of the industry to increase breast muscle yield and reduce fat deposition with better feed efficiency without compromising the normal growth rate of the birds (Mohammed and Horniakova, 2012)

The data in Table 1 shows that maximum mean percentage of abdominal fat deposition $(2.26 \%)$ was recorded with chickens fed the control diet (T0) while the lowest percentage value was recorded with chickens on diet T3 $(0.70 \%)$ whereas diets T1 (2.07) and T2 (1.12) recorded intermediate values. Applying DMRT it was discovered that mean values from diets $\mathrm{T} 0$ and $\mathrm{T} 1$ were similar $(\mathrm{P}>0.05)$ but significant $(\mathrm{P}<0.05)$ to $\mathrm{T} 2$ and $\mathrm{T} 3$. Abdominal fat deposition was observed to have a decreasing trend in ascending levels of S.molesta.

Since the tested diets were formulated to have relatively similar crude fat (Table 2) content the variations in the abdominal fat deposition in birds can be explained on the basis of the antinutrient content of S.molesta and the high crude fiber content of the diets. It is postulated that chickens fed with high amounts of fiber results in lower abdominal fat content and the present study further confirms this conclusion with treatment T3. This is in conformity with Saki et al. (2011) who observed that chickens fed diets containing high fiber 
attained lower abdominal fat content at 21 and 42 day of age. Also the influence of tannin on abdominal fat deposition cannot be ruled out. Contrasting results with Zulkarnain and Syahruddin (2008) who reported better abdominal fat deposition, performance and protein digestibility in broiler chickens was after fermenting of S.molesta but present experiment involved air dried S.molesta which resulted in suppressed BWG, carcass, breast muscle and abdominal fat deposition especially with $18 \%$ S.molesta inclusion level. These contrasting results could be attributed to form of S.molesta being used as broiler feed which could influence the presence of antinutrient factors and the nutrient quality and availability of the test diets. The result of this experiment differs to that mentioned by Widodo et al. (1996) who observed that feeding of high tannin sorghum (HTS) resulted in decrease carcass weight and increased abdominal fat while in the current experiment increasing S.molesta decreased both the carcass and abdominal fat content. This could be related to the broiler breed/strain being use as well as the protein to energy content of the diets and the level of dietary crude fiber and antinutrient factors available in the tested diets.

The average breast muscle percentages (Table 1) among the treatments show a similar pattern to that of abdominal fat content which shows a decreasing trend as the levels of S.molesta increased in the diets. The sizes of breast muscles could indicate the quality and utilization efficiency of diets by the birds and according to the results it would seem that birds fed treatment diets T2 and T3 poorly utilized their feed. This can indicate that the control diet had sufficient nutrients to support the breast muscle development in birds than the S.molesta inclusion diets. Among the S.molesta contained diets chickens fed T3 produced the lowest (28.61\%) breast muscle. This is probably due to the protein concentration and availability in the treatment diets. Diet T2 and T3 contained more of the S.molesta and the crude fiber contents are also high which could lead to the low protein availability to synthesize breast muscle thus attained the least breast muscle percentage. According to Williams (1997, as cited by Kumar et al., 2005) breast muscle yield depends on methionine and cysteine concentration in the diet, and methionine according to Gous et al. (1982) involves in the detoxification of tannin. Therefore, as S.molesta levels increased in the diets the amount of tannin also increased and this caused imbalance in the concentration of amino acids, therefore, presumably there was not sufficient amino acids available for the birds to meet their maintenance requirements as well as for breast muscle development resulting in lower breast muscle values noticed on diet T3. As reported by Saki et al. (2011) the negative effects of high crude fiber diets is more pronounced in chicks then mature birds. Therefore, the significantly depressed breast muscle values noted in the present trial could be provoked by both the tannin and high crude fiber content of the tested diets. The 6\% S.molesta inclusion was the appropriate level since higher amounts caused further depression in the breast muscle accretion among the broiler chickens.

\section{Conclusion}

Base on the results of this study it is obvious that the commonly used soybean meal in broiler diets can be successfully substituted by the Salvinia molesta however, the optimum inclusion level which produced consistent and better performance, breast muscle and abdominal fat results was $6 \%$. Further study is required to determine methods on how to utilize Salvinia molesta efficiently by broiler birds and other monogastric animals.

\section{Acknowledgement}

I would like to express my sincere gratitude to my advisors, Dr. Mahfudz and Prof Sumarsono for their tireless support in many ways. This study was a success because of you two gentlemen. I dedicated this paper to my loving brother late Steven Gani. You will be cherished and remembered forever.

\section{References}

[1]. Amrullah, K. Nutrisi ayam broiler. Lembaga satu gunungbudi, 2004, Bogor

[2]. AOAC, Official methods of analysis. 15 th edition (Association of official analytical Chemist, Washington, DC., 1990)

[3]. D'Mello, J. P. F. Toxic factors in some tropical legumes. World Review of Animal Production, 4, 1982, 41-46

[4]. Duncan, D. B. Multiple range and F-Test. Biometrics, 11, 1955, 1-42.

[5]. Golian, A and D. V. Maurice. Dietary poultry fat and gastrointestinal transit time of feed and fat utilization in broiler chickens. Poultry Science, 71(8), 1992, 1357-1363.

[6]. Gous, R. M., M. A. Kuyper, and C. Dennison. The relationship between tannic acid content and metabolizable energy concentration of some sorghum cultivars. South African Journal of Animal Science, 12, 1982, 39-44.

[7]. Hill, F. W. and L. M. Dansky. Studies on the energy requirements of chicks. Poultry Science, 33, 1954, 1034-1041.

[8]. I. R. Sibbald, Metabolizable energy evaluation of poultry diets, in D. J. A. Cole and W. Haresign (Ed.), Recent development in poultry nutrition, (UK: Butterworths, Essex, 1989) 12-26.

[9]. Kabir, J., M. A. Islam, M. U. Ahammad and M. A. R. Howlider. Use of duckweed in the diet of broiler. Indian J. Anim. Res., 39(1), 2005, 31-35

[10]. Kamran, Z., M. Sarwar, M. Nisa, M. A. Nadeem, S. Mahmood, M. E. Babar, and S. Ahmed. Effect of low protein diets having constant energy-to-protein ratio on performance and carcass characteristics of broiler chickens from one to thirty-five days of age. Poultry Science, 87, 2008, 468-474.

[11]. Kumar, V., A. V. Elangovan, and A. B. Mandal. Utilization of reconstituted high-tannin sorghum in the diets of broiler chickens. Asian Australian Journal of Animal Science, 18(4), 2005, 538-544. 
[12]. L. G. Butler, Sorghum polyphenols, in R. Cheekes (Ed.), Toxicants of Plant Origin, 4 (Boca Raton, Florida: CRC Press, 1989) 95114.

[13]. Leeson, S., J. D. Summers, and L. Caston. Growth response of immature brown-egg strain pullet to varying nutrient density and lysine. Poultry Science, 72, 1993, 1349-1358.

[14]. Ma'rifah, B., Atmomarsono, and N. Suthama. Nitrogen retention and productive performance of crossbred native chicken due to feeding effect of Kayambang (Salvinia molesta). International Journal of Science and Engineering, 5(1), 2013, 19-24.

[15]. McFarland, D. G., L. S. Nelson, M. J. Grodowitz, R. M. Smart and C. S. Owens. 2004. Salvinia molesta D.S. Mitchell (Giant Salvinia) in the United States: A Review of Species Ecology and Approaches to Management, ERDC/EL SR-04-2, U.S. Army Engineer Research and Development Center, Vicksburg, MS.

[16]. Medugu, C, I., I. D. Kwari, J. Igwebuike, I. Nkama, I. D. Mohammed, and B. Hamaker. Carcass and blood components of broiler chickens fed sorghum or millet as replacement for maize in the semi arid zone of Nigeria. Agriculture and Biology Journal of North America, 1, 2010, 2151-7517.

[17]. Mitchell, D. S. and N. M. Tur. The rate of growth of Salvinia molesta (S. auriculata auct.) in laboratory and natural conditions. Journal of Applied Ecology, 12, 1975, 213-225.

[18]. Mohammed, H. A. and E. Horniakova. Effect of using saturated and unsaturated fats in broiler diet on carcass performance. Slovak Journal of Animal Science, 45(1), 2012, 21-29.

[19]. Moozhiyil, M and J. Pallauf. 1986. Chemical composition of the water fern, Salvinia molesta, and its potential as feed source for ruminants. Economic Botany, 40(3), 1986, 375-383.

[20]. Muztar, A. J., H. J. Likuski, and S. J. Slinger. Metabolizable energy content of tower and candle rapeseeds and rapeseed meals determination in two laboratories. Canadian Journal of Animal Science, 58(3), 1978, 485-492.

[21]. National Research Council, Nutrient requirements of poultry. 9 th revised edition (National Academic Press, Washington, DC., 1994)

[22]. Nyachoti, C. M., J. L. Atkinson, and S. Leeson. Response of broiler chicks fed a high-tannin sorghum diet. Journal of Applied Poultry Research, 5(3), 1996, 239-245.

[23]. Ojewola, G. S., F. C. Okoye, and O. A. Ukoha. Comparative utilization of three animal protein sources by broiler chickens. International Journal of Poultry Science, 4970, 2005, 462-467.

[24]. Phuc, B. H. N., J. E. Lindberg, B. Ogle, and S. Thomke. Determination of the Nutritive Value of Tropical Biomass Products as Dietary Ingredients for Monogastrics Using Rats: 1. Comparison of Eight Forage Species at Two Levels of Inclusion in Relation to a Casein Diet. Asian Australian Journal of Animal Science, 14(7), 2001, 986-93.

[25]. Saki, A. A., H. R. Hemati Matin, P. Zamani, and F. Mirzaaghatabar. Non starch polysaccharides and broiler responses. World Applied Sciences Journal, 15(2), 2011, 192-198.

[26]. Uwalaka, R. E., J.P. Ihezuo, and E.O. Ahaotu. Effects of inclusion of unripe plantain peel meal (musa paradisca) on carcass quality, performance and internal organ weights in finisher broiler birds. International Journal of Agriculture and Biosciences, 2(4), 2013, $136-140$.

[27]. Widodo, W., Koentjoko, M. Kamal, and M. M. Ardhana. The effect of levels of two varieties of sorghum in the diets on broiler performance. Journal of Agricultural Science, 19, 1996, 107-109.

[28]. Widyaratne, G. P. and M. D. Drew. Effects of protein level and digestibility on the growth and carcass characteristics of broiler chickens. Poultry Science, 90(3), 2011, 595-603.

[29]. Williams, P. E. V. Poultry production and science: future directions in nutrition. World's Poultry Science Journal, 53(1), 1997, 3348.

[30]. Yu, F. The effect of condensed tannin upon the protein nutritional value of solvent extracted cottonseed meal for ruminant and monogastric animals, doctoral diss, Massey University, Palmerston North, New Zealand. 1995.

[31]. Zaman, Q., G. Suparno, and D. Hariani. Pengaruh Kiambang (Salvinia molesta) yang difermentasi dengan ragi tempe sebagai suplemen pakan terhadap peningkatan biomassa ayam pedaging. Lentera Biofarma, 2(1), 2013, 131-137.

[32]. Zulkarnain, H. and H. E. Syahruddin. Peningkatan qualitas Kiambang (Salvenia molesta) melalui pendekatan bioteknologi dengan beberapa jenis kapang sebagai pakan broiler (Fakultas Peternakan Universitas Andalas Padang. Sumatra, 2008) 